\title{
Efeito da eliminação genética das lipoxigenases das sementes sobre as características agronômicas da soja ${ }^{(1)}$
}

\author{
Carlos Alberto Osório Martins ${ }^{(2)}$, Carlos Sigueyuki Sediyama(3), Maurílio Alves Moreira(3), \\ Múcio Silva Reis ${ }^{(3)}$, Valterley Soares Rocha( ${ }^{(3)}$ e Maria Goreti de Almeida Oliveira ${ }^{(3)}$
}

\begin{abstract}
Resumo - A eliminação genética das enzimas lipoxigenases (Lox 1, Lox 2 e Lox 3) é uma das maneiras de se contornar os problemas associados ao sabor indesejável de "feijão cru" das sementes da soja. Visando elucidar a influência dessa eliminação genética nas características agronômicas da planta de soja e nos componentes de produção, a variedade comercial de soja FT-Cristalina RCH e suas linhagens, obtidas por retrocruzamentos, sem as três lipoxigenases nas sementes (linhagens triplo-nulas) e com as três lipoxigenases (triplo-positivas), foram avaliadas em três épocas de semeadura. A variedade comercial foi mais homogênea que as linhagens com ou sem lipoxigenases, indicando presença de quantidade significativa de genes dos progenitores não-recorrentes nas linhagens, principalmente nas sem lipoxigenases. A semeadura em diferentes épocas evidenciou variação entre os materiais genéticos (variedade comercial, linhagens com ou sem lipoxigenase nas sementes), tanto nas características da planta quanto nos componentes de produção de grãos. A eliminação genética das lipoxigenases das sementes não afetou negativamente as características agronômicas da variedade FT-Cristalina RCH.
\end{abstract}

Termos para indexação: Glycine max, sabor da soja, época de semeadura.

\section{Effect of genetic elimination of seed lipoxygenases on agronomic characteristics of soybean}

\begin{abstract}
The genetic elimination of lipoxygenase (Lox 1, Lox 2 and Lox 3) enzymes from soybean seeds is a way to overcome the problems associated with the undesirable beany flavor of soybean seeds. Aiming at elucidating the influence of this genetic elimination on the agronomic characteristics of the soybean plants and grain yield components, the commercial variety of soybean FT-Cristalina RCH and its backcross derived lines, lacking the three lipoxygenases in the seeds (triple-null) and with these enzymes (triple-positive) were evaluated at three sowing dates. The commercial variety was more homogeneous than the lines with or without lipoxygenases, indicating the presence of significant amount of genes of the non-recurrent progenitors in the lines, mainly in the triple-null. The different sowing dates evidenced more differences among genetic materials (commercial variety, triple-null and triple-positive lines), in plant characteristics and grain yield components. The genetic elimination of lipoxygenases of the seeds did not negatively affect the agronomic characteristics of FT-Cristalina RCH soybean variety.
\end{abstract}

Index terms: Glycine max, soybean flavor, sowing date.

\section{Introdução}

A soja (Glycine max (L.) Merrill) é a cultura de grãos mais importante do País. O complexo-soja, que compreende grãos, farelo e óleo, tem captado divisas no mercado internacional da ordem de US\$ 4 bilhões ao ano nas últimas safras (Câmara, 1998).

\footnotetext{
(1) Aceito para publicação em 24 de maio de 2002.

(2) Universidade Federal de Viçosa (UFV), CEP 36571-000 Viçosa, MG. Bolsista do Bioagro. E-mail: com@uepg.br

(3)UFV. E-mail: csediyama@ufv.br, moreira@ufv.br, msreis@ufv.br, vsrocha@ufv.br, malmeida@ufv.br
}

Os grãos de soja são utilizados em vários setores, merecendo destaque o setor alimentício, uma vez que possuem alto valor nutricional, pois são ricos em óleo e proteína de baixo custo. Porém, os produtos protéicos derivados dos grãos da soja não têm boa aceitação no mercado consumidor ocidental, em virtude do sabor e odor característicos, conhecidos como "beany flavor".

Esse sabor característico é, em grande parte, proporcionado pelas enzimas lipoxigenases (Lox 1, 2 e 3). A ação catalítica exercida por essas isoenzimas sobre ácidos graxos poliinsaturados, ácido linolênico e linoléico, dos grãos de soja é um dos principais 
fatores responsáveis pelo aparecimento dos compostos carbonílicos, os quais causam o sabor desagradável em grãos (Lanza, 1995).

Para melhorar as características organolépticas dos derivados da soja por meio de melhoramento genético, pesquisadores estão removendo essas isoenzimas das sementes de soja por meio de retrocruzamentos, resultando em linhagens com ausência de lipoxigenases, que produzem sementes com substancial melhoria de sua aceitação pelo consumidor (Sediyama et al., 1998).

No Programa de Melhoramento da Qualidade e do Sabor da Semente de Soja da Universidade Federal de Viçosa, as linhagens sem lipoxigenases são identificadas e confirmadas pelo emprego de marcadores de DNA e pela verificação da presença das lipoxigenases nas sementes. Paralelamente, o Programa visa, também, selecionar as linhagens que possuam as características agronômicas semelhantes aos progenitores recorrentes, para que possam ser semeadas pelos agricultores.

O objetivo deste trabalho foi comparar características agronômicas de linhagens de soja com e sem lipoxigenases nas sementes, para verificar se a eliminação genética dessas isoenzimas causa algum tipo de efeito nas características agronômicas dessa leguminosa.

\section{Material e Métodos}

O trabalho foi realizado no Campus da Universidade Federal de Viçosa (UFV), Viçosa, MG, no período de março de 1998 a junho de 1999. As análises das sementes foram realizadas no Laboratório de Biologia Molecular do Instituto de Biotecnologia Aplicada à Agropecuária (Bioagro), e no Laboratório de Sementes do Departamento de Fitotecnia da UFV.

A variedade de soja estudada foi FT-Cristalina $\mathrm{RCH}$, com as respectivas linhagens triplo-nulas, portadoras dos três pares de genes homozigotos recessivos $\left(\mathrm{x}_{1} l \mathrm{x}_{1} l \mathrm{x}_{2} l \mathrm{x}_{2} l \mathrm{x}_{3} l \mathrm{x}_{3}\right)$, que promovem a ausência das três lipoxigenases nas sementes, designadas FT-Cristalina RCH $\mathrm{TN}$ e as linhagens triplo-positivas, portadoras dos genes homozigotos dominantes $\left(\mathrm{Lx}_{1} \mathrm{Lx}_{1} \mathrm{Lx}_{2} \mathrm{Lx}_{2} \mathrm{Lx}_{3} \mathrm{Lx}_{3}\right)$, que promovem a presença das três lipoxigenases nas sementes, designadas FT-Cristalina RCH TP.

Essas linhagens TN e TP foram obtidas por meio de retrocruzamentos. Inicialmente, foi obtida a linhagem
FT-Cristalina 2,3 (CR 2,3), caracterizada pela ausência de Lox 2 e 3. Essa linhagem é proveniente dos cruzamentos de FT-Cristalina com Ichigowase (variedade sem Lox 3) e de outro cruzamento da FT-Cristalina com PI 86023 (Lox 2 ausente). Posteriormente, suas progênies foram intercruzadas para a obtenção da linhagem e apresentaram ausência das lipoxigenases 2 e 3 .

Sementes da linhagem CR 2,3 foram enviadas ao Japão, para cruzamentos com uma linhagem sem as três isoenzimas lipoxigenases (triplo-nulas), obtidas no National Agriculture Research Center, em Tsukuba, Japão. As sementes $F_{1}$ foram enviadas ao Bioagro e semeadas em casa de vegetação. As sementes $F_{2}$ obtidas foram selecionadas em relação à ausência das três lipoxigenases, através de métodos colorimétricos (Suda et al., 1995) e da determinação da atividade das lipoxigenases (Oliveira et al., 1998). Essas sementes foram cruzadas com a linhagem CR 2,3, originando-se o primeiro retrocruzamento. Posteriormente, foram realizados retrocruzamentos desse material com a variedade FT-Cristalina RCH. Sementes originárias do quarto retrocruzamento foram selecionadas, identificando-se aquelas triplo-nulas (TN) e aquelas triplo-positivas (TP), utilizadas neste trabalho. O processo de retrocruzamentos foi monitorado por marcadores moleculares, sendo utilizadas as plantas segregantes que mais se assemelhavam ao progenitor recorrente, isto é, apresentavam o menor índice de dissimilaridade com base nos marcadores moleculares.

Os tratamentos foram, portanto, designados FT-Cristalina RCH Comercial, FT-Cristalina RCH TN e FT-Cristalina RCH TP.

As sementes selecionadas foram semeadas para multiplicação, em casa de vegetação, nos meses de maio a junho de 1998 e a colheita, realizada manualmente, nos meses de setembro e outubro, para semeadura no campo, em três épocas ( 27 de outubro, 18 de novembro e 14 de dezembro de 1998), em terreno preparado com uma aração e duas gradagens, com aplicação do herbicida sulfentrazone, em pré-plantio, na dosagem de $1 \mathrm{~L} \mathrm{ha}^{-1}$. Aplicaram-se, no sulco de semeadura, $400 \mathrm{~kg} \mathrm{ha}^{-1}$ da fórmula 4-14-8. Em cada época, foram semeadas 10 linhas de cada genótipo de FT-Cristalina RCH Comercial, de FT-Cristalina RCH TP e de FT-Cristalina RCH TN.

Cada parcela era constituída de uma fileira de 2,5 $\mathrm{m}$ de comprimento, espaçada de $0,70 \mathrm{~m}$ uma da outra, com densidade de dez plantas por metro. Foram consideradas úteis as dez plantas centrais da fileira, e descartadas as demais. Foram feitas três capinas manuais, irrigação quando necessário, e controle de percevejo, por meio de duas pulverizações com a mistura de $30 \mathrm{~mL}$ de endossulfam e $6 \mathrm{~mL}$ de espalhante adesivo, em $20 \mathrm{~L}$ de água. 
As plantas foram colhidas manualmente, no período de abril a julho de 1999, no estádio de maturação R8 (Fehr et al., 1977) e secadas, em condições naturais, até as sementes apresentarem 10 a $11 \%$ de umidade. As vagens, contadas e debulhadas manualmente, foram armazenadas em câmara fria à temperatura de $4^{\circ} \mathrm{C}$ e umidade relativa de $50 \%$.

As seguintes características agronômicas foram avaliadas: número de dias para o florescimento (da semeadura até a abertura da primeira flor); altura da planta no florescimento (medida do nível do solo até a extremidade da haste principal); número de nós no florescimento (na haste principal, após o nó cotiledonar); número de dias para maturação (a partir da semeadura até que $95 \%$ das vagens atingissem a coloração típica de maduras, estágio R8); altura da planta na maturação (medida do nível do solo até a extremidade da haste principal); número de nós na maturação (na haste principal, a partir do nó cotiledonar); número de vagens (sementes formadas) por planta; número de sementes por planta; produção de sementes (peso em gramas de sementes por planta); e peso de 100 sementes (relação entre produção e número de sementes por planta, multiplicado por 100).

$\mathrm{O}$ experimento foi analisado conforme o delineamento inteiramente casualizado, com três tratamentos, avaliando-se, ainda, a variação entre linhas dentro de cada tipo de material genético, sendo as repetições as 10 plantas dentro de cada linha. As médias entre os tratamentos foram comparadas pelo teste de Tukey, a 5\% de probabilidade.

\section{Resultados e Discussão}

Houve interação significativa entre as épocas de semeadura e o tipo de material genético (Comercial, TN ou TP), exceto nas características número de vagens por planta, número de sementes por planta e produção de grãos por planta, o que indica que em cada época os diferentes materiais genéticos apresentaram variação de respostas quanto às características agronômicas avaliadas (Tabela 1). Na terceira época de semeadura, considerada tardia para Viçosa (Sediyama et al., 1996), o desenvolvimento das plantas foi menor (Tabela 2). Na primeira época de semeadura a temperatura, umidade do solo e as condições climáticas favoreceram o maior desenvolvimento e produção das plantas, e na terceira época, a temperatura e as condições climáticas influenciaram uma menor produção, por causa das baixas temperaturas do outono.

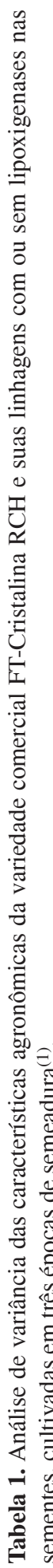




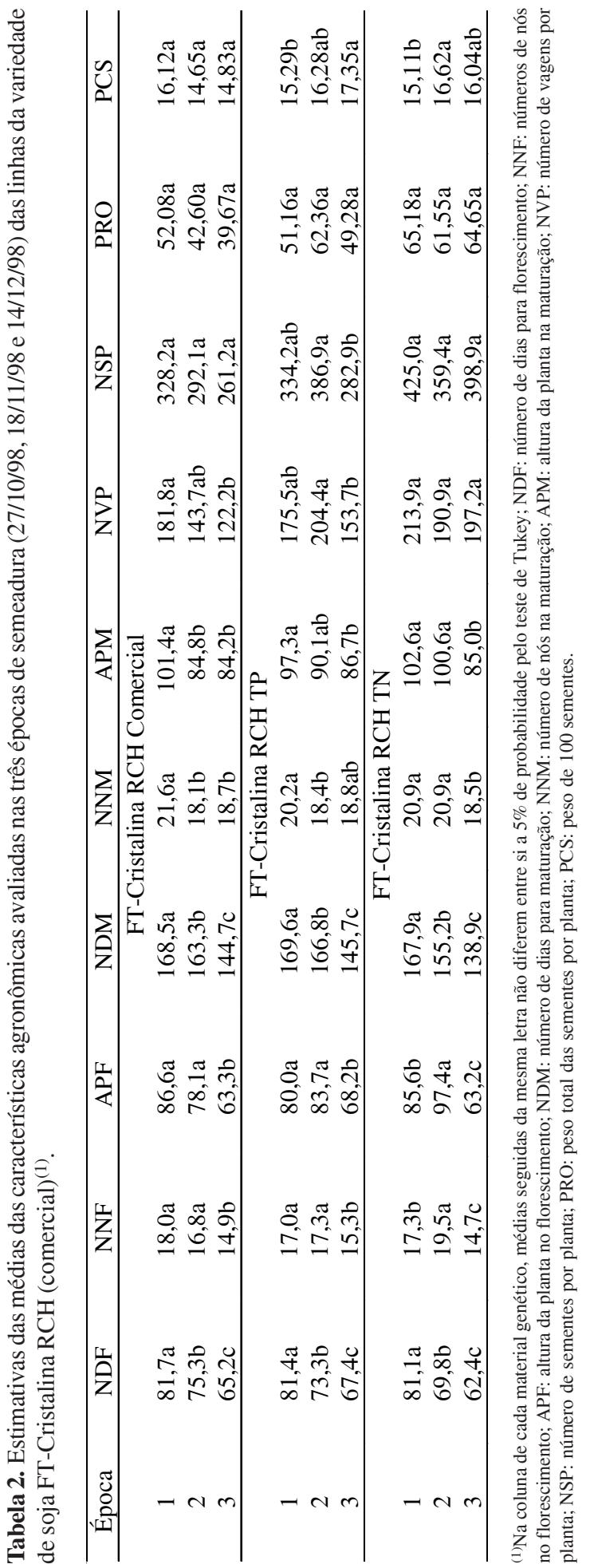

Os materiais genéticos, no geral, mostraram-se diferentes em todas as características analisadas, exceto em relação ao número de nós no florescimento (Tabela 1). A variabilidade entre linhas dentro de materiais genéticos $\mathrm{x}$ época de semeadura ocorreu em todas as características, exceto quanto ao número de nós na maturação (Tabela 1), e quanto às linhas dentro do material genético, dentro de cada época de semeadura ocorreu variação na maioria das características agronômicas estudadas (Tabelas 3, 4 e 5).

A produção de grãos e seus componentes apresentaram coeficientes de variação bastante elevados, 23,21 a 60,69\%, enquanto os caracteres relativos à planta apresentaram coeficiente de variação de 1,58 a 19,92\%. Esse resultado já era esperado, pois, por ser componente de variância ambiental de caracteres dependentes de todo o ciclo de determinado organismo, o coeficiente de variação da produção é o somatório de todas as variâncias morfológicas e fisiológicas dos caracteres que os afetam (Price \& Schluter, 1991), e os caracteres da planta exercem importante efeito sobre a produção.

As análises de variância dentro de cada época indicaram que as diferenças entre os materiais genéticos (comercial, com ou sem lipoxigenases) se evidenciaram na segunda e terceira época de semeadura, tanto nas características da planta quanto nos componentes de produção de grãos (Tabelas 3, 4 e 5). De acordo com Lynch \& Walsh (1998), a relação entre a variância herdável (diferença genética entre os materiais) e a total (herdável mais ambiental) pode ser maior ou menor, em diferentes ambientes, que no presente caso estão representados pelas épocas de semeadura.

Quanto à variabilidade das linhas dentro dos materiais genéticos, em todas as três épocas de semeadura, a variedade comercial foi mais homogênea que as linhagens com ou sem lipoxigenases derivadas, o que indica presença de variabilidade genética entre essas linhagens (Tabelas 3, 4 e 5). As linhagens TN apresentaram maior freqüência de variabilidade significativa quanto aos componentes de produção, do que a variedade comercial ou as linhagens TP, (Tabelas 6,7 e 8), o que é indicativo de que as linhagens TN apresentam, ainda, porção significativa de genes dos progenitores não-recorrentes. 


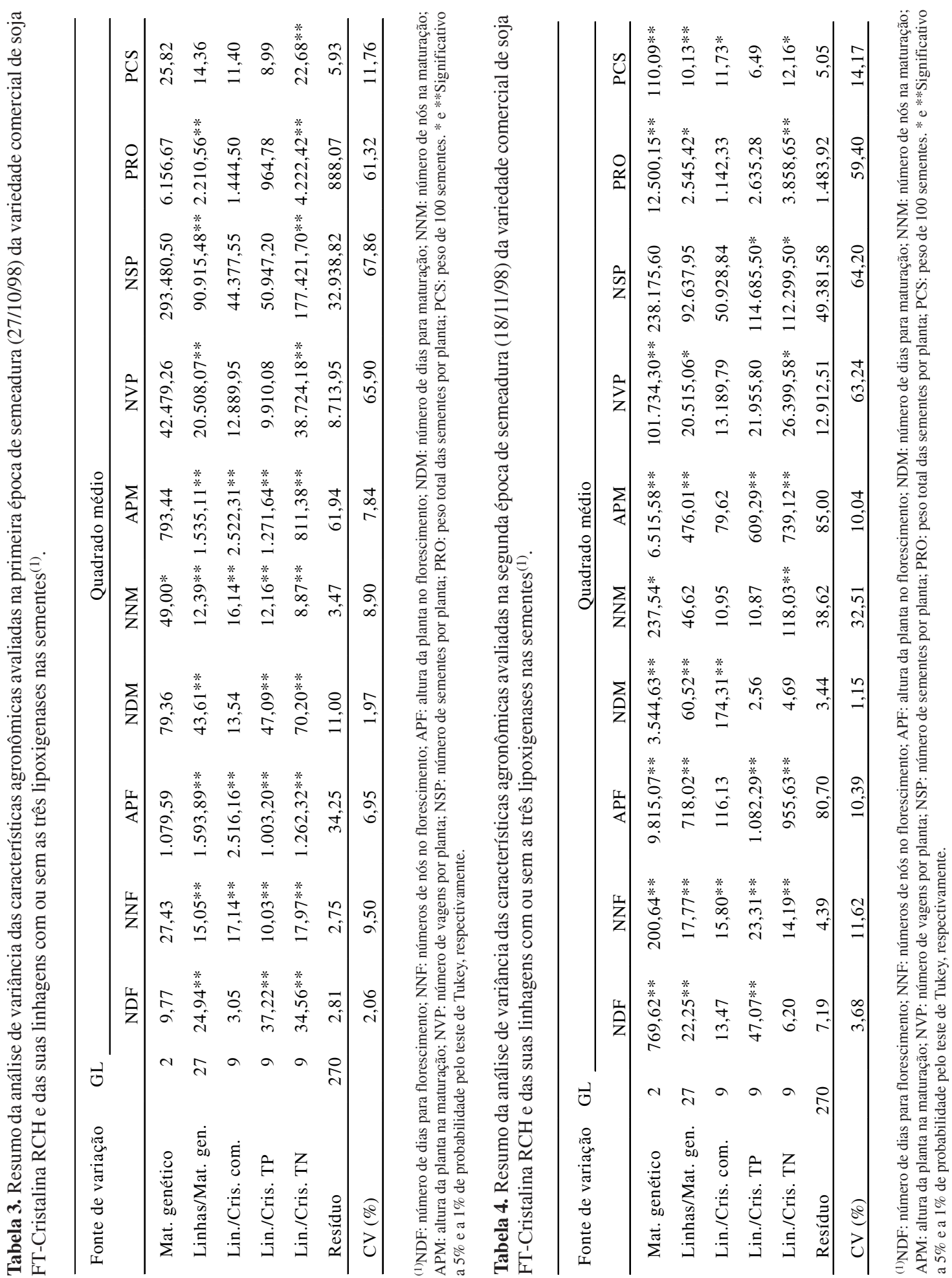




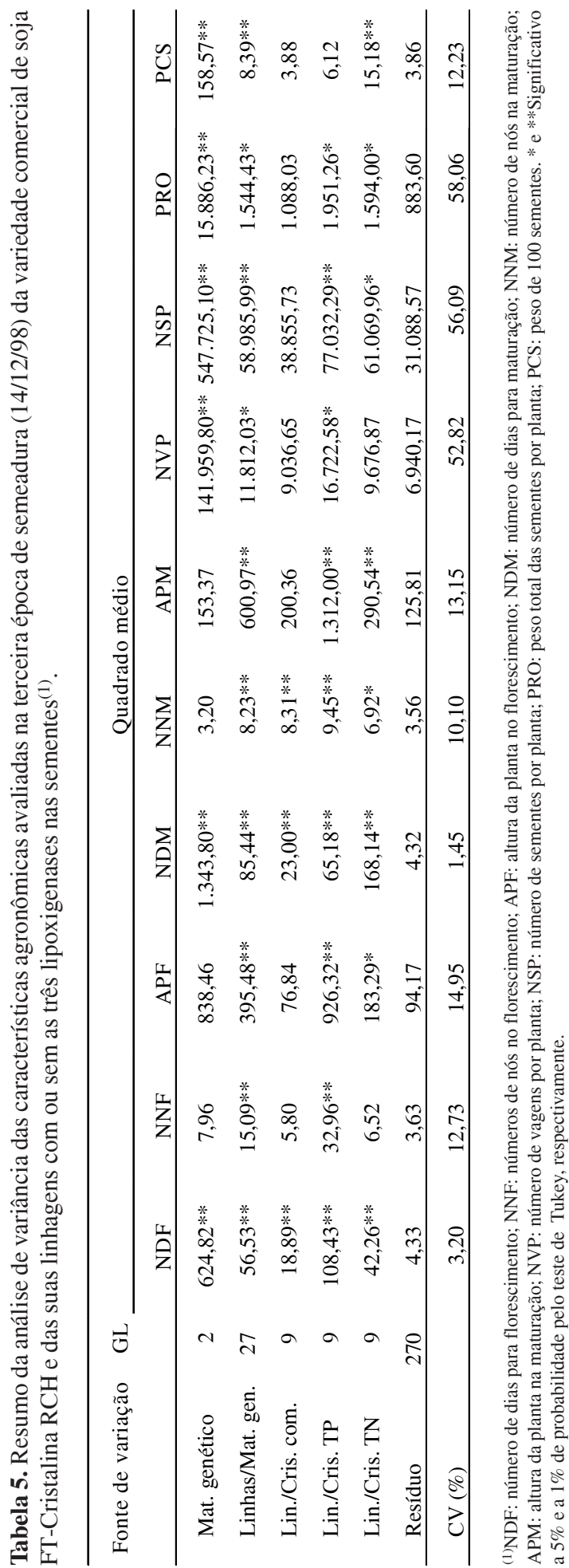

As diferentes frequiências e tipos de efeitos significativos entre as três épocas de semeadura pode ser indicativo de que diferentes genes estão sendo envolvidos nas diferentes épocas, apontando para uma composição genética diferenciada entre os três conjuntos de materiais avaliados. Isto é, o programa de retrocruzamentos, na fase avaliada, ainda não foi suficiente para homogeneizar o conjunto-gênico-base, indicando que ainda não se está trabalhando com linhas isogênicas.

Com relação ao desempenho das linhagens que sofreram eliminação genética das lipoxigenases, as linhas TN, quando comparadas com as linhas TP, ou mesmo com as da variedade comercial, não apresentaram maiores efeitos deletérios sobre as características agronômicas. Pelo contrário, nota-se a existência de linhas bastante promissoras entre as TN, o que indica o sucesso do programa de retrocruzamentos. A variabilidade entre as linhagens oriundas de retrocruzamentos, ou seja, a presença de variabilidade genética entre linhas TN, com linhas apresentando desenvolvimento vegetativo semelhante ou melhor que o material comercial e com componentes de produção (número de vagens por planta, número de sementes por planta e peso de 100 sementes) superiores, pode constituir-se em vantagem, pois poderão ser selecionadas linhas com ausência de lipoxigenases e agronomicamente superiores ao material original.

Taketa (2000), estudando linhagens triplo-nulas do Programa de Melhoramento de Soja para consumo humano, da UFV, também constatou que há linhagens TN com desempenho produtivo equivalente ao das variedades comerciais existentes, e que a ausência de três lipoxigenases nas sementes não afetou as características agronômicas avaliadas.

De acordo com Pfeiffer et al. (1992), isolinhas sem lipoxigenase 1 não trouxeram efeitos deletérios em várias características agronômicas estudadas, nem na germinação das sementes. Narvel et al. (1998), estudando linhagens sem as três lipoxigenases, também não observaram diferenças significativas entre as linhagens e a variedade comercial estudada, nas características agronômicas altura da planta, dias para maturação, peso de sementes, produção, e teores de óleo e proteínas das sementes. 


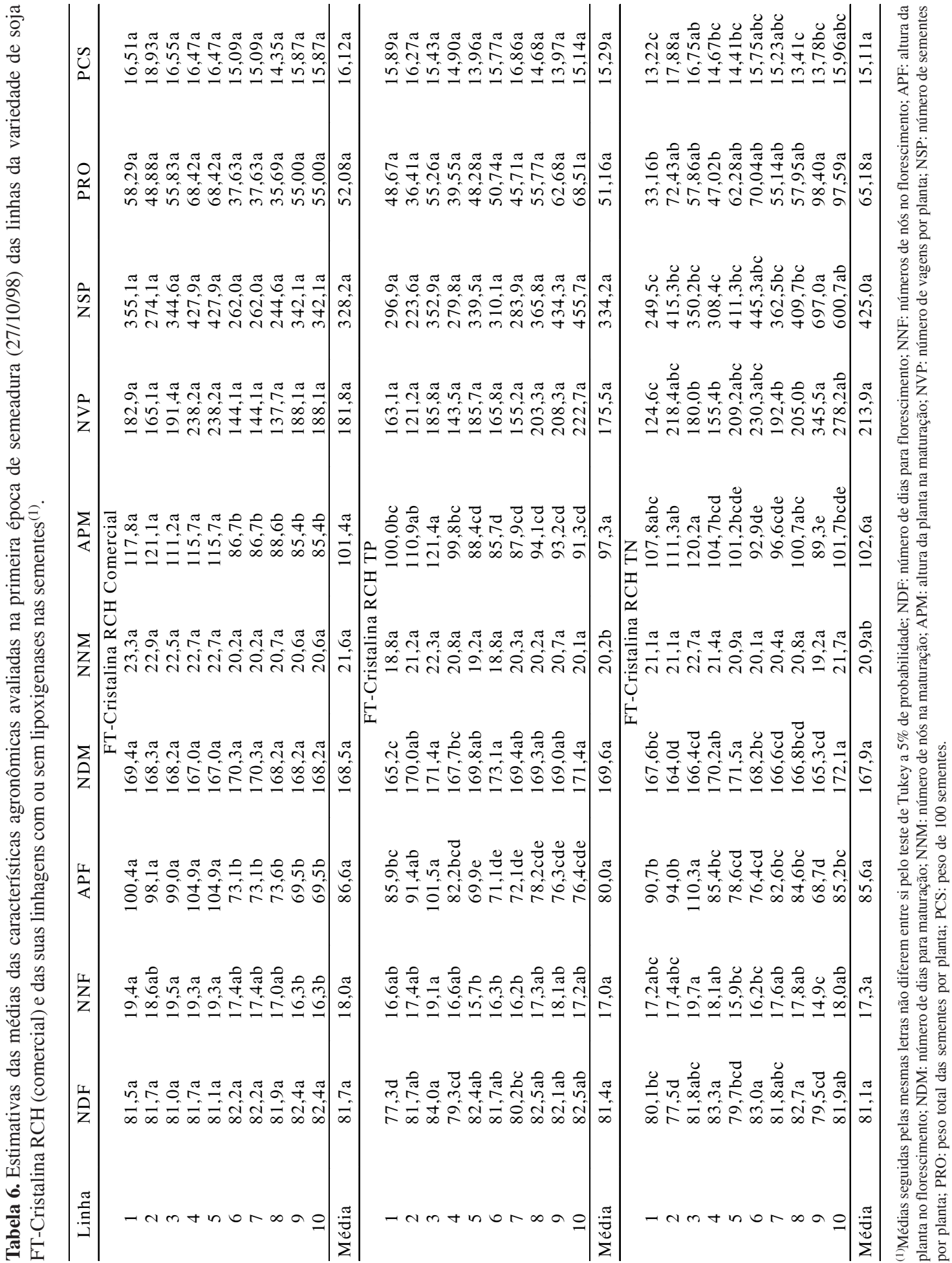




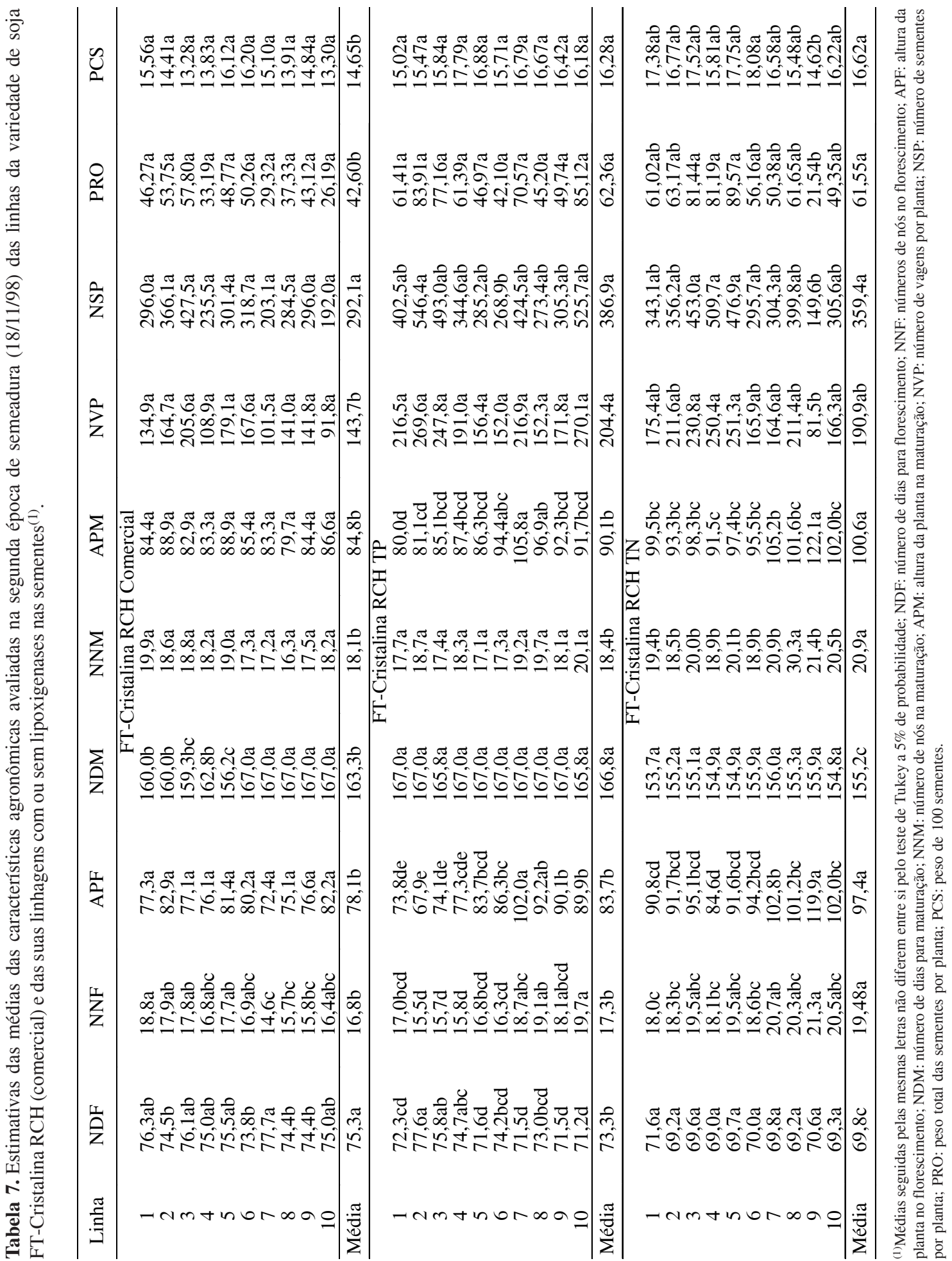




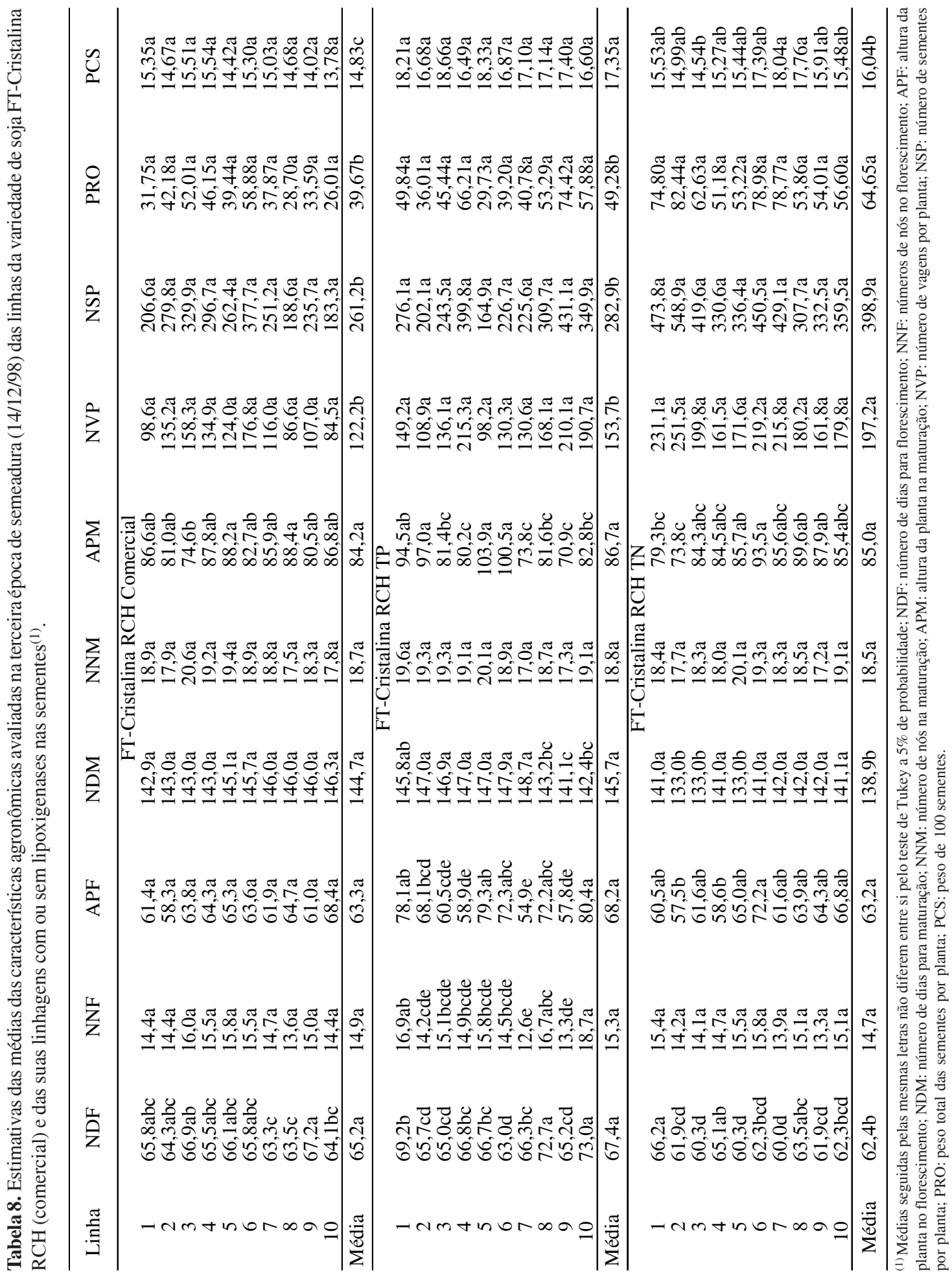




\section{Conclusões}

1. A variedade comercial é mais homogênea que as linhagens com ou sem lipoxigenases, o que indica presença de quantidade significativa de genes dos progenitores não-recorrentes, principalmente nas sem lipoxigenases.

2. A semeadura em diferentes épocas evidencia variação entre os materiais genéticos (variedade comercial, linhagens com ou sem lipoxigenase nas sementes), tanto nas características da planta quanto nos componentes de produção de grãos.

3. A eliminação genética das lipoxigenases das sementes não afeta negativamente as características agronômicas da variedade FT-Cristalina $\mathrm{RCH}$.

\section{Agradecimentos}

Ao Dr. Keisuke Kitamura do National Agriculture Research Center, Tsukuba, Japão, pelo fornecimento e multiplicação das sementes triplo-nulas.

\section{Referências}

CÂMARA, G. M. S. Soja: tecnologia de produção. Piracicaba: Esalq, 1998. 293 p.

FEHR, W. R.; CAVINESS, C. E.; BURMOOD, D. T.; PENNINGTON, J. S. Stage of soybean development. Ames: Iowa State University, 1977. 11 p. (Special Report, $80)$.

LANZA, M. A. Marcadores moleculares RAPD na introgressão de genes para ausência de lipoxigenases e da proteína A5A4B3 em soja (Glycine max (L.) Merrill). 1995. 57 f. Dissertação (Mestrado em Genética e Melhoramento) - Universidade Federal de Viçosa, Viçosa, MG, 1995.
LYNCH, M.; WALSH, B. Genetics and analysis of quantitative traits. Sunderland: Sinauer, 1998. 980 p.

NARVEL, J. M.; FEHR, W. R.; WELKE, G. A. Agronomic and seed traits of soybean lines lacking seed lipoxygenases. Crop Science, Madison, v. 38, p. 926-928, 1998.

OLIVEIRA, D. A.; PIOVESAN, N. D.; MORAES, R. M. A.; ROCHEBOIS, G. B.; OLIVEIRA, M. G. A.; BARROS, E. G.; MOREIRA, M. A. Identification of the three genotypic classes for soybean lipoxygenases 1 and 3 based on enzymatic activity. Biotechnology Techniques, London, v. 12, p. 71-74, 1998.

PFEIFFER, T. W.; HILDEBRAND, D. F.; TEKRONY, D. M. Agronomic performance of soybean lipoxygenase isolines. Crop Science, Madison, v. 32, p. 357-362, 1992.

PRICE, T.; SCHLUTER, D. On the low heritability of life-history traits. Evolution, Lawrence, v. 45, p. 853-861, 1991.

SEDIYAMA, C. S.; QUEIROZ, L. R.; MOREIRA, M. A.; REZENDE, S. T. Aldehyde production and physiological quality of soybean seeds lacking lipoxygenase isozymes. In. WORLD SOYBEAN RESEARCH CONFERENCE, 5., 1994, Chiang Mai. Proceedings... Bangkok: Kasetsart University Press, 1998. p. 441-446.

SEDIYAMA, T.; PEREIRA, M. G.; SEDIYAMA, C. S.; GOMES, J. L. L. Cultura da soja, II. Viçosa, MG: UFV, 1996. 75 p. (Boletim Técnico, 212).

SUDA, I.; HAJIKA, M.; NISHIBA, Y.; FURUTA, E.; IGITA, K. Simple and rapid method for the selective detection of individual lipoxygenase isozymes in soybean seeds. Journal of Agricultural and Food Chemistry, Washington, v. 43, p. 742-747, 1995.

TAKETA, S. T. Comportamento da soja (Glycine max (L.) Merrill) com ausência de três isoenzimas lipoxigenases, em diferentes épocas de plantio, em duas localidades de Minas Gerais. 2000. 69 f. Dissertação (Mestrado em Fitotecnia) - Universidade Federal de Viçosa, Viçosa, MG, 2000. 